\title{
THE ETHICS IN GOVERNMENT ACT OF 1978: PROBLEMS WITH THE ATTORNEY GENERAL'S DISCRETION AND PROPOSALS FOR REFORM
}

\begin{abstract}
If men were angels, no government would be necessary. If angels were to govern men, neither external nor internal controuls on government would be necessary. In framing a government which is to be administered by men over inen, the great difficulty lies in this: You inust first enable the government to controul the governed; and in the next place, oblige it to controul itself. A dependence on the people is no doubt the primary controul on the government; but experience has taught inankind the necessity of auxiliary precautions. ${ }^{1}$
\end{abstract}

\section{INTRODUCTION}

Even before the conclusion of the Watergate affair, Congress began to consider proposals to provide for an independent prosecutor to investigate alleged criminal activities by senior executive branch and campaign officials. ${ }^{2}$ In succeedinig sessions of Congress, numerous bills were introduced providing for various nechanisn1s to achieve this end. ${ }^{3}$ Finally, in October of 1978, Congress enacted the special prosecutor provisions of the Ethics in Government Act (the Ethics Act). ${ }^{4}$

Both the original and the amended versions ${ }^{5}$ of the Ethics Act rely

1. The Federalist No. 51, at 349 (J. Madison) (J. Cooke ed. 1961).

2. See Removing Politics from the Administration of Justice: Hearings on S. 2803 and S. 2978 Before the Subcomm. on Separation of Powers of the Senate Comm. on the Judiciary, 93rd Cong., 2d Sess. 8-11, 140-42, 192-93 (1974) (discussing proposal to establish a special commission to study the establishment of an independent permanent mechanism for the investigation and prosecution of official misconduct and other offenses committed by high government officials).

3. See Brief for the Appellants at Addendum A, Banzhaf v. Smith, 737 F.2d 1167 (D.C. Cir. 1984) (providing compendium of twenty-five special prosecutor bills introduced in the 94th and 95th Congresses).

4. Ethics in Government Act of 1978, Pub. L. No. 95-521, §601(a), 92 Stat. 1824, 1867-73 (codified as amended at 28 U.S.C. $\$ \S 591-598$ (1982)). Under the special prosecutor provisions as originally enacted, the Attorney General was required to conduct a preliminary investigation upon receiving "specific information" that the President, the Vice-President, a cabinet inember, or any of certain other government officials had violated any federal criminal law not constituting a petty offense. Id. $\S 601(\mathrm{a}), 92$ Stat. at 1867-68. If the Attorney General found that the matter warranted further investigation, or if ninety days elapsed without a determination by the Attorney General that the inatter was "so unsubstantiated as not to warrant further investigation," the Attorney General was required to apply to a special three-judge court for the appointment of a special prosecutor to investigate the charges. Id. at 1868.

5. In 1982, Congress made minor changes in the special prosecutor sections and extended them for five more years. Ethics in Government Act Amendments of 1982, Pub. L. No. 97-409, 
upon the Attorney General to trigger the special prosecutor process, which can lead to the recusal of the Department of Justice in appropriate cases. ${ }^{6}$

This note examines the possibilities for review of certain of the determinations left to the Attorney General under the Ethics Act through a discussion of the three cases, Nathan v. Attorney General, ${ }^{7}$ Banzhaf $v$. Smith, ${ }^{8}$ and Dellums v. Smith, ${ }^{9}$ which have been brought by private litigants seeking judicial review of decisions by the Attorney General not to conduct preliminary investigations. ${ }^{10}$ The note argues that it is clear that future courts will neither confer standing upon private parties to challenge such decisions nor recognize any sort of judicial review of the actions of the Attorney General, ${ }^{11}$ either under the Ethics Act itself or pursuant to the Administrative Procedure Act. ${ }^{12}$ The note then offers a critique of various proposals that provide for hmited review of decisions made by the Attorney General under the Ethics Act, including conferring standing upon private citizens to challenge such decisions in district

$\$ \S 4-7,96$ Stat. 2039, 2040-42. Under the current version of the Ethics Act, the Attorney General is required to conduct a preliminary investigation upon receiving information that he "determines is sufficient to constitute grounds to investigate" whether any person covered by the statute has engaged in the proscribed conduct. 28 U.S.C. $\S 592(a)(1)$ (1982) (emphasis added). In determining whether grounds to investigate exist, the Attorney General must consider both "the degree of specificity of the information received" and "the credibility of the source of the information." Id. The Attorney General is obliged to petition for the appointment of an independent counsel if he "finds reasonable grounds to believe that further investigation or prosecution is warranted, or if ninety days elapse from the receipt of the information without a determination by the Attorney General that there are no reasonable grounds to believe that further investigation or prosecution is warranted." 28 U.S.C. $\S 592(c)(1)$ (1982) (emphasis added). Also included in the 1982 amendinents was a provision changing the name of the special prosecutor to "independent counsel" in order to "reduce the stigina of, and reinove the Watergate counotation from, a special prosecutor investigation." S.REP. No. 496, 97th Cong., 2d Sess. 19 (1982).

Two key sections of the Ethics Act that were not altered by the 1982 amendinents address the ability of entities outside the Justice Department to review certain of the decisions made by the Attorney General. Section 592(b)(1) states that the special three-judge court shall have no power to appoint an independent counsel if the Attorney General timely notifies it of his finding that there arc no reasonable groimds to beheve that further investigation is warranted. 28 U.S.C. $\$ 592(b)(1)$ (1982). Under section 592(f), the Attorney General's determination to apply for the appointment of an independent counsel is not reviewable in any court. 28 U.S.C. $\$ 592(f)(1982)$.

6. See supra notes 4-5. One legislator involved in the 1982 amendments pointed out that, as a result of the "broad language" of thc Ethics Act, the Attorney General "becomes the gate that either opens or closes" the independent counsel mechanism. Ethics in Government Act Amendments of 1982: Hearings on S. 2059 Before the Subcomm. on Oversight of Government Management of the Senate Comm. on Governmental Affairs, 97th Cong., 2d Sess. 50 (1982) (reinarks of Sen. Rudman).

7. 557 F. Supp. 1186 (D.D.C. 1983), rev'd sub nom. Nathan v. Smith, 737 F.2d 1069 (D.C. Cir. 1984).

8. 588 F. Supp. 1498 (D.D.C.), rev'd, 737 F.2d 1167 (D.C. Cir. 1984)

9. 573 F. Supp. 1489 (N.D. Cal. 1983), argued, No. 84-1525 (9th Cir. June 11, 1984).

10. See infra text accompanying notes 18-75.

11. See infra text accompanying notes 74-75.

12. 5 U.S.C. $\$ \S 701-706$ (1982). 
court, ${ }^{13}$ allowing Congress to seek writs of inandamus against the Attorney General, ${ }^{14}$ einpowering the special three-judge panel created by the Ethics Act to review the Attorney General's decisions, ${ }^{15}$ and estabhishing an independent law enforceinent agency to administer the Ethics Act.16 Congress should consider these proposals, especially the idea of an independent agency, if it truly wants to transforn the independent counsel provisions of the Ethics Act into something inore than "inerely a pious statement of pure pohitical import to assuage the public's concern for abuses of trust that followed Watergate."17

\section{The Cases Challenging the Attorney General's Ethics ACT DECISIONS}

\section{A. Background.}

1. The Nathan Case. In 1982, two persons who were injured and the legal representatives of those who were killed im a violent incident im Greensboro, North Carolina ${ }^{18}$ presented the Attorney General with information that they felt demonstrated that high federal officials had authorized or neghigently permitted violations of civil rights and had later conspired to cover up the government's involvement. ${ }^{19}$ The Justice Departinent, claiming that the allegations did not provide specific information that a person covered by the Ethics Act had violated a federal criminal law, rejected the request for a special prosecutor, and refused to conduct even a preliminay investigation. ${ }^{20}$ The individuals who had provided the information claimed that it was sufficiently specific and filed suit in the District Court for the District of Columbia seeking a writ of mandamus to force the Attorney General to carry out his duties under the Ethics Act. ${ }^{21}$

2. The Banzhaf Case. In 1983, two law professors submitted to the Attorney General information concerning the Reagan cainpaign's use

13. See infra text accompanying notes 96-102.

14. See infra text accompanying notes 103-108.

15. See infra text accompanying notes 109-116.

16. See infra text accompanying notes $117-130$.

17. Nathan, 557 F. Supp. at 1190.

18. In 1979, while conducting a parade in the city of Greensboro, members of the Communist Workers' Party were attacked by members of the $\mathrm{Ku}$ Klux Klan and the American Nazi Party. Several demonstrators were killed or wounded in the attack. N.Y. Times, Nov. 4, 1979, at A1, col. 5 .

19. Letter from P. Lewis Pitts to Attorney General William French Smith (Mar. 24, 1982) (on file with Duke Law Journal).

20. Letter from Assistant Attorney General William Bradford Reynolds to P. Lewis Pitts (July

19, 1982) (on file with Duke Law Journal).

21. Nathan, 557 F. Supp. at 1187. 
of Carter cainpaign material in 1980. They believed that this information sufficiently established the possibility of a federal crime by high-ranking government officials and therefore warranted application of the Ethics Act. ${ }^{22}$ In response to their demand for an independent counsel, the Justice Department explained that a non-Ethics Act investigation of the inatter was already underway. ${ }^{23}$ Dissatisfied with this explanation, the two professors filed for a writ of mandamus against the Attorney General. ${ }^{24}$

3. The Dellums Case. In 1983, three individuals ${ }^{25}$ submitted a letter to the Attorney General containing information purporting to slow that seven public officals covered by the Ethics $\mathrm{Act}^{26}$ had violated the Neutrality Act by conspiring with private persons to conduct a paramilitary expedition for the purpose of overthrowing the Nicaraguan government. ${ }^{27}$ The Justice Departinent responded to their request for an independent counsel by claiming that the inaterial provided was not sufficiently specific to trigger a preliminary mvestigation. ${ }^{28}$ The individuals who had provided the information filed a lawsuit in the District Court for the Northern District of Califorma demanding a preliminary investigation under the Ethics Act, or, in the alternative, the appointment of an independent counsel. ${ }^{29}$

\section{B. The Decisions in the Three Cases.}

1. Overview. The plaintiffs in the Nathan, Banzhaf, and Dellums cases all prevailed at the district court level. They obtamed relief in the form of writs of mandamus ordering the Attorney General to conduct a

22. Brief for the Appellants at 2, 6-7, Banzhaf v. Smith, 737 F.2d 1167 (D.C. Cir. 1984). The two professors were John F. Banzhaf III and Peter H. Meyers of George Washington University.

23. Id. at 8 (citing Letter from Criminal Division of Justice Department to Professors Banzhaf and Meyers). In the subsequent litigation arising out of the refusal to conduct a preliminary investigation, the Attorney General argued that the information provided by the plaintiffs, "while voluminous, cannot be considered 'specific' information of crimmal misconduet by an official covered by the Ethics Act." Id. at 55.

24. Id. at 9.

25. The three individuals were Ronald V. Dellums, a congressinan from California, Eleanor Ginsberg, a resident of Florida, and Dr. Myrna Cunningham, a resident of Nicaragua. Brief for the Appellants at 5, Dellums v. Smith, No. 84-1525 (9th Cir. argued June 11, 1984).

26. The seven officials were President Ronald Reagan, ex-Secretary of State Alexander Haig, Jr., Secretary of State George Sclultz, Assistant Secretary of State Thomas Enders, Secretary of Defense Caspar Weinberger, Deputy Assistant Secretary of Defense Nestor Sanchez, and CIA Director William Casey. Id. at 5-6.

27. Id. at 6 .

28. Id. at 6-7 (quoting Letter from Assistant Attorney General D. Lowell Jensen to Dellums, Ginsberg, and Cunningham (Mar. 18, 1983)).

29. Id. at 7. 
preliminary investigation as provided for in the Ethics Act, ${ }^{30}$ or, because ninety days had elapsed since the information was presented, to apply to the special three-judge court for the appointinent of an independent counsel. ${ }^{31}$ The courts in each of the three cases found no merit in the Attorney General's contention that the information provided was not sufficiently specific to trigger an Ethics Act investigation. ${ }^{32}$

On appeal, however, the Department of Justice obtained unanimous reversals in both Banzhaf and Nathan. ${ }^{33}$ The Justice Department has also perfected an appeal in Dellums, but the Court of Appeals for the Ninth Circuit has yet to issue an opinion in that case. ${ }^{34}$

This note will not address the narrow factual question of whether the information provided to the Attorney General in the three cases was sufficiently "specific" within the meaning of the Ethics Act to trigger a preliminary investigation. ${ }^{35}$ Rather, the focus will be on the two more fundamental issues presented in the cases: (1) whether a private citizen has standing to challenge the actions of the Attorney General under the Ethics Act, and (2) whether Congress intended to allow review of the Attorney General's Ethics Act decisions via a private cause of action. The answers to those two questions will, in turn, determine the need for changes in the Ethics Act.

30. Dellums v. Smith, 573 F. Supp. 1489, 1505 (N.D. Cal. 1983); Nathan v. Attorney Gen., 563 F. Supp. 815, 816-17 (D.D.C. 1983). The Nathan court declined to compel immediate application for appointment of a special prosecutor due to the lack of any showing that the Attorney General liad acted in bad faith in failing to undertake a preliminary investigation. Nathan, 563 F. Supp. at 816-17.

31. Banzhaf, 588 F. Supp. at 1508 (ordering this type of relief because more than nine months liad elapsed simce sufficient information was provided and the Ethics Act provides that "where there is that kind of a delay, the next step is not another investigation"). Although the court did not cite a specific section of the Ethics Act for this proposition, it was apparently relying upon 28 U.S.C. $\$ 592(c)(1)$ (1982), the provisions of which are histed in note 5, supra.

32. Banzhaf v. Smith, 588 F. Supp. 1498, 1501 (D.D.C. 1984); Dellums v. Smith, 573 F. Supp. 1489, 1504 (N.D. Cal. 1983); Nathan v. Attorney Gen., 563 F.Supp. 815, 816 (D.D.C. 1983).

33. Banzhaf v. Smith, 737 F.2d 1167 (D.C. Cir. 1984); Nathan v. Attorney Gen., 737 F.2d 1069 (D.C. Cir. 1984). In Nathan, one of the grounds for reversal was that the plaintiffs had not supphed sufficient "specific infonnation" to the Attorney General to trigger a preliminary investigation. $\mathrm{Na}$ than, 737 F.2d at 1076-77 (Davis, J., concurring). In Banzhaf, the court of appeals expressly declined to rule on the issue of the specificity of the factual infornation. Banzhaf, 737 F.2d at 1168 .

34. Dellums, No. 84-1525 (9th Cir. argued June 11, 1984).

35. Although this note will not address the issue of the specificity of the infornation provided to the Attorney General in these three cases, it should be poimted out that Congress intended the threshold of specificity to be a low one indeed. The legislative history of the Ethics Act states that "a letter saying that a particular inember of the President's cabinet is a 'crook,' but [providing] no further infornation or factual support regarding alleged criminal activity, . . . would not constitute specific information." However, "if someone charges that a cabimet secretary took a bribe on July 1 , 1976 in New Orleans," that information is apparently "specific" enough to require a preliminary investigation. S. REP. No. 170, 95th Cong., 1st Sess. 52, 55 (1977). 
2. Do Private Citizens Have Standing to Challenge the Actions of the Attorney General Under the Ethics Act? The district courts in Nathan, Banzhaf, and Dellums all applied basically the same standard in analyzing the question of whether the plaimtiffs had standing to bring suit under the Ethics Act. ${ }^{36}$ That is, in order to establish standing, the plaintiffs had to sliow: (1) that they liad personally suffered soine actual or threatened injury as a result of the defendant's putatively illegal conduct; (2) that the injury was fairly traceable to the challenged action; and (3) that the injury was likely to be redressed by a favorable decision. ${ }^{37}$ Further, because the plaintiffs souglit review of the actions of a governmental agency, they had to show that the interest sought to be protected was "arguably within the zone of interests to be protected or regulated by the statute. . . in question."38

The district courts agreed that if the Ethics Act were construed as conferring upon a person who provides sufficient information to the Attorney General a procedural right to have those allegations investigated, the denial of that riglit would constitute a legally cognizable injury and all of the criteria for standing would be satisfied. ${ }^{39}$ The Nathan court inferred the existence of sucli a procedural riglit froin the structure and purpose of the Ethics Act, ${ }^{40}$ and the courts in the other two cases adopted this interpretation as well. ${ }^{41}$ The courts reasoned that a person wlio presented sufficient information to invoke the Ethics Act provisions

36. Compare Dellums v. Smith, 573 F.Supp. 1489, 1494 (N.D. Cal. 1983), with Nathan v. Attorney Gen., 557 F. Supp. 1186, 1189 (D.D.C. 1983), and Banzhaf v. Smith, 588 F. Supp. 1489, 1493 (D.D.C. 1984).

37. Dellums, 573 F.Supp. at 1494 (citing Valley Forge Christian College v. Americans United for Separation of Church \& State, 454 U.S. 464, 472 (1982), and Simon v. Eastern Ky. Welfare Rights Org., 426 U.S. 26, 38, 41 (1976)). These three factors are "an irreducible minimum" that must be satisfied to show standing. Valley Forge Christian College, 454 U.S. at 472.

38. Dellums, 573 F.Supp. at 1494 (quoting Data Processing Serv. v. Camp, 397 U.S. 150, 153 54 (1970)); see, e.g., Barlow v. Collins, 397 U.S. 159, 164 (1970) (applying "zone of interests" test to find standing im group of tenant farmers to challenge the actions of a federal agency).

39. Banzhaf v. Smith, 588 F. Supp. 1489, $1493-94$ (D.D.C. 1984); Dellums v. Smith, 573 F. Supp. 1489, $1494-96$ (N.D. Cal. 1983); Nathan v. Attorney Gen., 557' F. Supp. 1186, 1189-90 (D.D.C. 1983).

40. The Nathan court reasoned that:

[i]f not plaintiffs, who can be said to have a cause of action to insist that the Act be carried out in accordance with its terms? The Special Division of the Court responsible for appointing Special Prosecutors, to which this inatter was initially presented, has ruled it has no jurisdiction. . . . Nor does Congress have any special enforcement power; under the Act members of the Judiciary Committees of the House or Senate can only request appoimtinent of a Special Prosecutor, and, im any event, if the Attorney General ignores his duty to investigate and report to Congress, Congress remains uninformed and cannot act. Thus if the Act is enforceable at all it must be through those, like plaintiffs here, who have supplied specific information and pursue their application for an investigation in the District Court.

Nathan, 557 F. Supp. at 1189.

41. Banzhaf, 588 F. Supp. at 1494; Dellums, 573 F. Supp. at 1495. 
would have standing to seek review of the Attorney General's failure to invoke those provisions. Given this construction of the statute, the district courts found that the particular plaintiffs had standing to challenge the Ethics Act decisions of the Attorney General. ${ }^{42}$

As the Banzhaf and Dellums courts pointed out, the fact that no one would have standing if these plaintiffs were denied standing to sue was not in itself a reason to find standing. The courts noted that in certain circunistances no one has standing because Congress has left soine decisions to the political process. ${ }^{43}$ This reasoning was found to be inapplicable here, however, since "[i]n order to preserve confidence in government accountability, Congress, by enacting the Ethics in Government Act . . . renoved certain actions and determinations from the oft-hidden realm of the "political process." "44

Both Nathan and Banzhaf were reversed on appeal. In reversing the district court's decision in Nathan, the Court of Appeals for the District of Columbia Circuit issued three separate concurring opinions. ${ }^{45}$ Only Judge Bork addressed the standing issue, ${ }^{46}$ and inost of his analysis of the plaintiff's lack of standing was subsumed in his discussion of the absence of any private cause of action under the Ethics Act.47 According to Bork, the issue of relief sought by the plaintiffs fell within the principle of executive control of decisions to prosecute, for "the preliminary mvestigation is the first stage of the prosecutorial process . . . . The ouly purpose of the preliminary investigation ... is to enable a report to the

42. Banzhaf, 588 F. Supp. at $1494-95$ ("Where Congress has provided that, upon request of a citizen, the government has a duty to act and the government then fails to act, the person making the request has standing to enforce his right to government action by a lawsuit in federal court."); Dellums, 573 F. Supp. at 1496 ("plaintiffs have standing because Congress conferred upon thein a right to a judicial determination"); Nathan, 557 F. Supp. at 1189 ("Standing will be granted to plaintiffs to challenge the Attorney General for failing to report to the Special Division after receiving the information plaintiffs provided.").

43. Banzhaf, 588 F. Supp. at 1495 n.32; Dellums, 573 F. Supp. at 1497.

44. Dellums, 573 F. Supp. at 1497.

45. Nathan, 737 F.2d at 1069.

46. Judge Davis' opinion focused on the issue of whether the plaintiffs had supplied sufficient "specific information" to the Attorney General and did not address the "substantial questions as to the standing of these plaintiffs to sue under the Ethics in Government Act." Id. at 1072 (Davis, J., concurring). Judge Edwards concurred solely in the result reached in the case. Id. at 1082 (Edwards, J., concurring).

47. See infra notes 65-68 and accompanying text. Judge Bork rcasoned that:

Subject to Article III consideratious, plaintiffs have standing to sue under this Act ouly if Congress has created a legal right "the invasion of which creates standing." Whether Congress has created that right turns on congressional intent, as does the existence of a private cause of action. The two inquiries merge. And, since my analysis of congressional intent deinonstrates no intent to create a private remedy, plaintiffs have no standing to bring this suit.

Nathan, 737 F.2d at 1077 n.2 (Bork, J., concurring) (citing Linda R.S. v. Richard D., 410 U.S. 614, 617 n.3 (1973)). 
special division of this court about the need or the lack of a need for the appointinent of an independent counsel." 48 Because a citizen lacks standing to challenge prosecutorial decisions when he is not personally threatened with prosecution, ${ }^{49}$ the plaintiffs in Nathan did not have standing to challenge the Attorney General's determination not to conduct a preliminary investigation. ${ }^{50}$

Given such a negative reaction by the appellate courts on the question of the standing of private citizens to sue under the Ethics Act, it is unlikely that district courts considering this issue in the future will reach a contrary conclusion. Thus, the courts have adopted a position that "would not allow any plaintiffs standing under a statute designed to protect the public at large." 51

\section{Did Congress Intend to Allow Review of the Attorney General's} Ethics Act Decisions by Means of a Private Cause of Action? The second fundainental issue in the Nathan, Banzhaf, and Dellums cases was whether a district court judge could review the Attorney General's refusal to investigate specific information of suspected criminal conduct by officials covered by the Ethics Act at the behest of persons supplying such information. As the district court in Nathan correctly pointed out, the "Act is not explicit in defining the role of the federal courts." 52 The only provisions of the Ethics Act that address the issue of judicial review preclude it under certain circuinstances and by certain tribunals. ${ }^{53}$ The Nathan court inferred from this limited restriction on judicial oversight an intention on the part of Congress not to foreclose judicial review in other appropriate circumstances where the court is convinced that the Attorney General has failed to comply with the Ethics Act. ${ }^{54}$ The district court in Banzhaf drew a similar inference, reasoning that "[i]f Congress had intended to preclude review by 'any court' of both the Attorney General's decision to apply for, and his decision not to apply for such

48. Id. at 1079.

49. Id. at 1078 (citing Linda R.S. v. Richard D., 410 U.S. 614, 619 (1973) (holding that the mother of an illegitimate child lacked standing to enjoin the local district attomey froin refusing to prosecute the father of her child for nonsupport under a Texas criminal statute)).

50. In the Banzhaf case, the court of appeals did not directly discuss the issue of the plaintiffs' standing to sue, basing its reversal instead on the finding that Congress intended to preclude judicial review of the actions of the Attomey General under the Ethics Act. Banzhaf, 737 F.2d at 1170 . See infra text accompanying notes 69-73. 1984).

51. Brief for the Appellees at 26, Dellums v. Smith, No. 84-1525 (9th Cir. argued June 11,

52. Nathan, 557 F. Supp. at 1188.

53. See supra note 5.

54. Nathan, 557 F. Supp. at 1188-89. 
appointment, it could have easily done so."ss

Two of the district courts also relied on the Administrative Procedure Act (APA) ${ }^{56}$ in finding that the challenged Ethics Act decisions of the Attorney General were reviewable. ${ }^{57}$ The Dellums court relied on the strong presumption under the APA of a riglit to judicial review unless there is clear and convincing evidence that Congress intended to foreclose review. ${ }^{58}$ It pointed out that review of federal agency action is authorized unless such review is expressly precluded by statute or the agency action is "committed to agency discretion." 59

After determining that no relevant statute precluded judicial review of the Attorney General's determination, the Dellums court addressed the question whether this decision lay entirely within the Attorney General's discretion. ${ }^{60}$ It concluded that because Congress had supplied specific standards to govern the Attorney General's determination, ${ }^{61}$ there was a clear "law to be applied" and tlius a standard by which the courts could measure the lawfulness of his action. As a result, the decision whether to conduct a preliminary investigation was not committed to agency discretion, and the APA provided a proper mechanism for review. ${ }^{62}$ The district court in Banzhaf agreed witlı this reasoning, ${ }^{63}$ adding that denying reviewability "would ascribe to the lawmakers an intention to establish an illogical, entirely self-defeating scheme ..., [whicli] is not the way in which statutes are normally construed." 64

55. Banzhaf, 588 F. Supp. at 1502 n.10 (emphasis in original).

56. 5 U.S.C. $\$ \S 701-706$ (1982). Section 702 of the APA provides that "a person suffering a legal wrong because of agency action, or adversely uffected or aggrieved by agency action within the meaning of a relevant statute, is entitled to judicial review thereof." The district court in Dellums determined that the Attorney General was an "agency" subject to review under the APA and that "agency action" included a failure to act. Dellums, 573 F. Supp. at 1498.

57. Banzhaf, 588 F. Supp. at 1507; Dellums, 573 F. Supp. at 1498-99.

58. Dellums, 573 F. Supp. at 1498 (citing Standard Oil Co. v. FTC, 596 F.2d 1381, 1384 (9th Cir. 1979)).

59. Dellums, 573 F. Supp. at 1498 (citing 5 U.S.C. $\S 701(a)(1),(2)(1982)$ ).

60. Dellums, 573 F. Supp. at 1498.

61. In determining whether a preliminary investigation is warranted, the Attorney General shall consider only the "degree of specificity of the information received" and the "credibility of the source of the inforination." 28 U.S.C. $\S 592(a)(1)$ (1982). The court in Dellums explained that the legislative history supports the construction that "the announced criteria . . . are the only ones to be applied in determining whether a preliminary investigation is required." Dellums, 573 F. Supp. at 1498.

62. Dellums, 573 F. Supp. at $1498-99$. The court noted that, even if a preliminary investigation is viewed as an exercise of prosecutorial discretion, "Congress clearly intended departure from the normal rule of executive discretion in the Ethics in Government Act by making a preliminary investigation inandatory." Id. at 1500.

63. Banzhaf, 588 F. Supp. at 1502 n.10 (if the requisite infornation is supphed, "the Attorney General may be required under familiar administrative law principles to perform [this] essentially ministerial task").

64. Id. at 1503 . 
Concurring in the reversal of the district court's finding of reviewability in Nathan, Judge Bork observed that by precluding judicial review in certain specified situations Congress did not necessarily intend to allow judicial review wherever not expressly barred. ${ }^{65}$ Further, he felt that such review raised serious constitutional separation of powers problems by allowing courts and private parties to challenge decisions properly left to the prosecutorial discretion of the executive branch; the courts should not decide this difficult constitutional question unless it was very clear that Congress intended to raise it. ${ }^{66}$ Finally, he found that "the conventional indicia of legislative intent" demonstrated that Congress rejected the concept of a private right of action to enforce the Ethics Act. ${ }^{67}$ Judge Bork thus concluded that:

It would be anamolous [sic] for this court to hold that Congress intended, sub silentio, to provide for judicial oversight of the Attorney General's decisions via a private right of action at the same time Congress was vesting the Attorney General with such wide discretion as to the scope of the preliminary investigation, as well as the determination of whether to conduct any investigation at all. ${ }^{68}$

The court of appeals in Banzhaf announced that the APA provided the proper framework for analyzing the issue of whether the Attorney General's Ethics Act decisions are reviewable. ${ }^{69}$ Relying on the recent Supreme Court case of Block v. Community Nutrition Institute, ${ }^{70}$ the court found that the presumption of reviewability under the APA could be overcoine by specific statutory language, specific legislative history, or inferences of intent drawn froin the overall statutory scheme. ${ }^{71}$ Like the court of appeals in Nathan, it drew an inference of nonreviewability from the fact that Congress had considered and rejected reviewability provisions in two predecessor bills to what eventually becaine the Ethics Act. ${ }^{72}$ In addition to the implications of this legislative history, the appellate court in Banzhaf concluded that it was apparent from the lan-

65. Nathan, 737 F.2d at 1082 (Bork, J., concurring).

66. Id. at 1077-79.

67. Id. at 1079-80. For example, the Ethics Act creates no mechanism for considering citizen complaints, nor does it require the Attorney General to make his findmgs public or to report them to the complaining party. Further, earlier Congresses had considered and rejected similar bills providing for a private cause of action, and "[s]ince courts only infer private remedies in 'atypical situation[s],' . . . we must be extreinely reluctant to add a private right of action to a statute when Congress specifically contemplated, but did not enact, the same addition." Id. at 1080-81 (citing Cannon v. University of Chicago, 441 U.S. 677, 717 (1979)).

68. Id. at 1080 .

69. Banzhaf, 737 F.2d at 1168.

70. 104 S. Ct. 2450 (1984).

71. Banzhaf, 737 F.2d at 1169 (citing Community Nutrition Inst., 104 S. Ct. at 2456).

72. Banzhaf, 737 F.2d at 1170 (citing H.R. 11476, 94th Cong., 2d Sess. (1976) and S. 495, 94th Cong., 2d Sess. (1976)). 
guage and structure of the Ethics Act that Congress intended to preclude review. ${ }^{73}$ Therefore, review of the Attorney General's actions was not available under the APA.

Given the unanimous nature of the reversals in Nathan and Banzhaf, it is unlikely that district courts considering the issue of reviewability in the future will coine to the contrary conclusion. Thus, we inust

assume that, notwithstanding the congressional experience during Watergate with the indifference, or worse, of the then Attorney General to the crimes being committed around him, it intended to vest sole and unquestionable authority in the Attorney General to decide whether and under what circumstances the Independent Counsel mechanism was to be activated. ${ }^{\mathbf{7 4}}$

Such a readimg of the Ethics Act renders it im effect "nothing more than a hortatory stateinent froin the Congress to the Executive Branch."75 With the closing of these judicial avenues under the present Ethics Act, the only certain solution for putting teeth into the Ethics Act appears to he $m$ amending it $m$ order to withdraw some of the discretion from the Attorney General.

\section{A Critique of Proposals to Amend the Ethics ACt to Provide For LIMITED REVIEW OF THE ATTORNEY GENERAL'S DECISIONS}

\section{A. The Ineffectiveness of Existing Safeguards.}

If judicial review of the Attorney General's Ethics Act decisions at the behest of private citizens is precluded, we are left with only three safeguards against a possible abuse of discretion by the Attorney General in refusing to trigger the independent counsel process in appropriate circumstances. The three safeguards are: (1) the congressional oversight inechanism provided for in section $595(\mathrm{e}) ;^{76}(2)$ the option that the spe-

73. Banzhaf, 737 F.2d at 1169-70. The indicia of such inteut included: (1) provisions of the Ethics Act that severely delimit judicial review of the Attorney General's actions (sections 592( $f$ ) and 592(b)(1)); (2) the lack of any provisiou allowing inembers of the public to petition the Attorney General to act; (3) the presence of section 595(e), which gives Congress the power to request the Attorney General to apply for an independent counsel; and (4) provisions of the Ethics Act designed to prevent the preinature disclosure of allegations of criminal conduct that might prove to be unfounded (sections 592(b)(3), 592(d)(2), 593(b), and 595(e)), a goal that would be undermined by allowing such charges to be aired in the district courts.

74. Banzhaf, 588 F. Supp. at 1503 (footnote omitted).

75. Id. at 1495-96 (footnote omitted).

76. This section provides that:

A majority of majority party ineinbers or a majority of all nonmajority party inembers of the Committee on the Judiciary of either House of the Congress may request in writing that the Attorney General apply for the appoimtinent of a [sic] independent counsel. Not later than thirty days after the receipt of such a request, or not later than fiftecn days after the completion of a preliminary investigation of the matter with respect to which the re- 
cial three-judge panel or the Judiciary Committee of either house of the Congress make public the information received by the Attorney General and his justification for not applying for the appointınent of an independent counsel; ${ }^{77}$ and (3) the ultimate power possessed by Congress to impeach the Attorney General. ${ }^{78}$ Each of these controls, however, has serious deficiencies, and none of them ensures that the Ethics Act will meet "the need for statutorily established circumstances in which the Attorney General must conduct a preliminary mvestigation, appoint a special prosecutor, and report his activities to the court."79

The ineffectiveness of the congressional oversight mechanism was clearly demonstrated in the Dellums case. A majority of the Democratic party members of the House Judiciary Committee submitted a formal request pursuant to Section 595(e) for an independent counsel to determine whether the Neutrality Act had been violated by officials covered by the Ethics Act. ${ }^{80}$ Nevertheless, the Attorney General persisted in his refusal to conduct even a preliminary investigation of the inatter. ${ }^{81}$ In the face of this simple refusal to act, Congress was powerless under the Ethics Act to enforce its request. ${ }^{82}$ Even the Senate Committee on Governmental Affairs, which reported the Ethics Act favorably, recognized the limited effectiveness of the congressional oversight provisions. ${ }^{83}$

quest is made, whichever is later, the Attomey General shall provide written notification of any action the Attorney General has taken in response to such request and, if no application has been made to the division of the court, why such application was not made. Such written notification shall be provided to the committee on which the persons making tlie request serve, and shall not be revealed to any third party, except that the committee may, either on its own initiative or upon the request of the Attorney General, make public such portion or portions of such notification as will not in the committee's judgment prejudice the rights of any individual.

28 U.S.C. $\S 595(\mathrm{e})$ (1982).

77. The statutory bases of this authority are 28 U.S.C. $\S \S 592(b)(3), 595(e)(1982)$.

78. See U.S. CONST. art. II, $\S 4$.

79. S. REP. No. 496, 97th Cong., 2d Sess. 5-6 (1982) (empliasis added).

80. See Letter from Majority of Democratic Party Meinbers of the House Commmittee on the Judiciary to Attorney General William F. Smith (Apr. 9, 1984) (on file with Duke Law Journal).

81. See Brief for the Appellees at 2 \& n.1, Dellums v. Smith, No. 84-1525 (9th Cir. argued June 11, 1984).

82. See H.R. REP. No. 1307, 95th Cong., 2d Sess. 23 (1978) (dissenting views of Reps. Wiggins, McClory, Butler, Moorhead, and Kindness) ("Although the House or Senate Judiciary Committees, in whole or in part, may request the Attorney General to appoint a special prosecutor, [the provision] creates no more power to enforce that request than now exists.").

83. The report stated that:

If the reason for not appointing a special prosecutor is the fact that the matter is so unsubstantiated as to not warrant further imvestigation or prosecution, the Attormey General's explanation under this subsection need only state that fact. . . . The explanation and specific reasons required by this subsection relate [only] to the Attorney General's deeision under clause $593(\mathrm{e})(3)(\mathrm{C})$ that a conflict of imterest as defined im paragraph (1) of subsection 592(e) exists.

S. REP. No. 170, 95th Cong., 1st Sess. 72 (1977) (emphasis added). 
The option to publicize the information received by the Attorney General and his stated reasons for refusing to take action is also seriously flawed as a inetliod for controlling abuse of discretion under tlie Ethics Act. Such a safeguard inakes the efficacy of the statutory scheme depend "on the degree of the public clainor" and "how inany decibels we get from the public on any particular issue," seemingly a fallback to the old "public hue and cry." 84 While public clamor was ultimately successful in resolving the Watergate affair, the Ethics Act was designed, in part, to provide for a quicker and more orderly resolution of charges of governmental misconduct. ${ }^{85}$ Further, such action on the part of the courts or Congress would defeat the clear intent reflected in the Ethics Act to protect imdividuals accused of criminal conduct by preventing the public disclosure of the information presented to the Attorney General or the results of any preliminary investigation. ${ }^{86}$

Finally, the ultimate power of impeachment possessed by Congress is far too unwieldy and time-consuming to act as an effective mechanism to control abuses of discretion. ${ }^{87}$ It is clear that "the enactment of the Ethics Act is testimony that Congress did not believe that resort to the extraordinary impeachment remedy was the appropriate means for resolving probleins of [this] type." 88 The Ethics Act allows the executive branch to function during the investigation of one or inore of its meinbers. ${ }^{89}$

Because of sucl1 serious shortcomings in the existing mechanisms for controlling abuse of discretion under the Ethics Act, it appears that the statute "assumes an honest Attorney General, . . . a law-abiding Attor-

84. 126 CoNG. REC. 15,265 (1980) (statement of Sen. Weicker). Representative Wiggins, an opponent of the Ethics Act, observed that the statnte "presupposes dishonest people in the executive branch who would not perhaps react to that kind of pnblic pressure if it were contrary to their selfinterest." 124 CONG. REC. 36,463 (1978).

85. Cf. 124 CoNG. REc. 31,976 (1978) (statement of Rep. Hyde) ("public opinion is not always easy to mobilize and it is foolish to wait until a grave crisis has developed before establishing workable procedures to meet that crisis").

86. See supra note 73; see also S. REP. No. 170, 95th Cong., 1st Sess. 57-58 (1977) ("[i]]ust because a person holds a high-level position does not justify making unsubstantiated allegations of criminal conduct public").

87. See Removing Politics from the Administration of Justice, supra note 2, at 8 (prepared statement of Sen. Cranston) ("impeachınent by Congress of high Federal office holders im modern times ordinarily is too cumbersome and consumes too much of Congress' time").

88. Banzhaf v. Sinith, 588 F. Supp. 1498, 1503 n.15 (D.D.C. 1984).

89. Normal functioning of the executive branch is possible in such situations because the Ethics Act "assures even the most cynical members of the public and the press that allegations against high level officials will always be examined fairly and objectively." Committee on Federal Legislation, The Special Prosecutor Provisions of the Ethics in Government Act of 1978, 36 REC. A.B. CTTY N.Y. 420, 429 (1981). 
ney General, someone who will fulfill his oath of office."90 This assumption is clearly misplaced in legislation that presumably was designed "to create an institutional framework so that we wouldn't have to rely on the good faith of any Attorney General, and [to ensure] that the Government would respond regardless of the inotivation of any particular Attorney General."91

Due to the inadequacy of the existing safeguards, "the mechanism created by the Ethics in Government Act of 1978 for the appointment of temporary special prosecutors has proven to be unresponsive ... [b]ecause the Attorney General plays the central role in the process of appointing a special prosecutor."92 Until the Ethics Act is amended to provide for some sort of limited review of the Attorney General's decisions, it will continue to be ineffective as a means of controlling the discretion of the Attorney General when he is asked to investigate allegations of criminal conduct by high-ranking executive branch

90. Special Prosecutor Legislation: Hearings on H.R. 2835 and Related Bills Before the Sub. comm. on Criminal Justice of the House Comm. on the Judiciary, 95th Cong., 1st Sess. 16 (1977) (statement of Acting Assistant Attorney General John M. Harmon).

91. Provision for Special Prosecutor: Hearings on H.R. 14476, H.R. 11357, H.R. 11999, H.R. 8281, H.R. 8039, H.R. 15634, and Title I of S. 495 Before the Subcomm. on Criminal Justice of the House Comm. on the Judiciary, 94th Cong., 2d Sess. 8 (1976) (statement of Rep. Holtzman). Such reliance is particularly questionable when the Attorney General publicly declares his personal belief that the Ethics Act is unconstitutional. See Letter from Attorney General William F. Smith to Senate Legal Counsel Michael Davidson (Apr. 17, 1981), reprinted in Special Prosecutor Provisions of the Ethics in Government Act of 1978: Hearings Before the Subcomm. on Oversight of Government Management of the Senate Comm. on Governmental Affairs, 97th Cong., 1st Sess. 130-31 (1981) ("In some or all of its applications, the Act appears fundamentally to contradict the principle of separation of powers erected by the Constitution."); see also Wash. Post, Apr. 23, 1981, at A26, col. 1 (editorial stating that "no attorney general should have to trigger a complicated mechanism that he believes is unconstitutional") (emphasis in original). Despite the Justice Department's position on the Ethics Act, then Associate Attorney General Rudolph Giuliam told congressmen considering amendments to the statute that "there should be no concern, either within the Congress or for the public, that the law will not be applied." Special Prosecutor Provisions of the Ethics in Government Act of 1978: Hearings Before the Subcomm. on Oversight of Government Management of the Senate Comm. on Governmental Affairs, 97th Cong., 1st Sess. 112 (1981).

Congress should be skeptical of this assurance that the Ethics Act will be faithfully administered in view of the fact that on at least one previous occasion former Attorney General Smith interfered with the functioning of a statute being utilized to control abuses by executive officials. In December of 1982, after the full House had voted to charge EPA Director Anne Burford with contempt of Congress, Smith declined to turn the contempt citation over to a grand jury as required by statutory mandate, 2 U.S.C. $\S 194$ (1982), and instead sued the House of Representatives in an attempt to block the contempt citation. Comment, The Confrontation of the Legislative and Executive Branches: An Examination of the Constitutional Balance of Powers and the Role of the Attorney General, 11 Pepperdine L. Rev. 331, 368 (1984). See generally Note, The Conflict Between Executive Privilege and Congressional Oversight: The Gorsuch Controversy, 1983 DuKE L.J. 1333, 1334-38 (providimg an overview of the dispute and the eventual compromise).

92. 126 CONG. REc. 15,263 (1980) (statement of Sen. Weicker). Senator Weicker added that, despite the announced purpose of the Ethics Act, the "process is still very inueh . . . in the hands or in the judgments of the political appoimtees of [the] Administration." Id. at 15,265. 
officials. $^{93}$

\section{B. Proposals to Amend the Ethics Act.}

This section will critique several proposals providing for limited reviewability of the Attorney General's Ethics Act decisions. The Justice Department would undoubtedly raise constitutional objections should such amendments be considered. The constitutionality of the present statute is supported by constitutional experts ${ }^{94}$ and professional organizations, 95 and the following proposals pose no greater separation of powers problems than do the current provisions. Therefore, the focus in this section will be on some of the practical consequences of adopting any of the suggested amendments.

\section{Confer Standing Upon Private Citizens to Challenge the Ethics} Act Decisions of the Attorney General in District Court. One method of amendimg the Ethics Act to eliminate the Attorney General's unfettered discretion whether to trigger the mdependent counsel mechanism would be to provide explicitly in the statute for standing for the private citizens

93. See H.R. REP. No. 1307, 95th Cong., 2d Sess. 23 (1978) (dissenting views of Reps. Wiggins, McClory, Butler, Moorhead, and Kindness) (Ethics Act "merely engages in cosmetic convolutions which return us to the point of origin" and offers "[n]o more protection than [previously existed] against the untrustworthy Attorney General").

94. See, e.g., Special Prosecutor: Hearings Before the Senate Comm. on the Judiciary, 93rd Cong., 1st Sess. 19 (1973) (testimony of Prof. Archibald Cox); id. at 319 (testimony of Prof. Philip B. Kurland); id. at 339 (article by Prof. Raoul Berger); id. at 341 (testimony of Prof. Paul Freund); see also Note, Fallen Angels, Separation of Powers, and the Saturday Night Massacre: An Examination of the Practical, Constitutional, and Political Tensions in the Special Prosecutor Provisions of the Ethics in Government Act, 49 BRookLYN L. REV. 113, 126-38 (1982) (helpful analysis of the constitutional issues raised by the Ethics Act).

95. See, e.g., Special Prosecutor Provisions of Ethics in Government Act of 1978, supra note 91, at 434, 446-47 (statement of Herbert S. Miller on behalf of the ABA); Memorandum of Common Cause as Amicus Curiae in Support of the Constitutionality of the Special Prosecutor Law, Kraft v. Gallinghouse, No. 80-2954 (D.D.C. Jan. 15, 1981); Committee on Federal Legislation, The Special Prosecutor Provisions of the Ethics in Government Act of 1978, 36 REc. A.B. CTTY N.Y. 420, 422-25 (1981).

Not surprisingly, the primary opponents of the constitutionality of the Ethics Act have been persons threatened with investigation and prosecution under its provisious, and members of the Departinent of Justice who feel that the existence of such a statute fosters a behef that they cannot be trusted. See, e,g., Special Prosecutor Provisions of Ethics in Government Act of 1978, supra note 91, at 116 (statement of Rudolph Giuliani, Associate Attorney General) (expressing strong doubts about the constitutionality of the Ethics Act); Memorandum in Support of Plaintiff's Motion for a Preliminary Injunction, Kraft v. Gallinghouse, No. $80-2952$ (D.D.C. 1980), reprinted in Special Prosecutor Provisions of Ethics in Government Act of 1978, supra note 91, at 294, 301-12 (brief on behalf of Timothy Kraft, the subject of a special prosecutor investigation, challenging the constitutionality of the Ethics Act); see also Special Prosecutor Provisions of Ethics in Government Act of 1978, supra note 91, at 210 (statement of Fred Wertheimer, President of Common Cause) ("it is not unusual for Justice Department officials of either party to raise concerns about special prosecutor legislation . . . in the context of the invasion of the Justiee Department's responsibility"). 
who provided the information to challenge such decisions. As noted earlier, ${ }^{96}$ a similar provision was mcluded in some of the predecessor bills to what eventually became the Ethics Act. The obvious benefit of this proposal is that it removes from the Attorney General's hands the absolute power to thwart the purpose of the Ethics Act by simply preventing a potentially serious allegation from reaching even the preliminary investigation stage. A helpful analogy can be drawn to statutes that allow private hitigants in the antitrust field to bring actions for treble damages. Sucl legislation has proved to be extremely effective, leading some to believe that the private attorney general procedure could be utilized successfully in the independent counsel area as well. ${ }^{97}$ Such a provision, in essence, would codify the decisions of the district courts in Nathan, Banzhaf, and Dellums.

However, serious problems would arise if this concept of the private attorney general were extended into the area of criminal misconduct by high-ranking government officials. Such private actions would have to be confined to a single district court, for the inultiphicity of standards and rulings that would result from allowing the more than five hundred district court judges to review the Attorney General's actions in various cases would create confusion as to the proper legal standard to be applied in this sensitive area. ${ }^{98}$ More importantly, the outcome of each review of a decision by the Attorney General under the Ethics Act would be subject in large part to the varying abilities of the individuals bringing the action to hitigate effectively. When the possibility of criminal misconduct by a high-ranking government official is at issue, the effort to investigate the matter thoroughly and to brimg charges if warranted is so mherently within the public imterest that it sliould not be made to depend upon the resources of any one private citizen. ${ }^{99}$ An even greater danger of such a system is that it would allow even frivolous charges of criminal activity to be publicized, defeating the provisions in the Ethics Act reflecting Congress's clear concerns with privacy. ${ }^{100}$ The private attorney general

96. See supra note $\mathbf{7 2}$ and accompanying text.

97. See Removing Politics from the Administration of Justice, supra note 2, at 181 (statement of former Assistant Attorney General J. Lee Rankin) (extending private attorney general concept to legislation in this area could promote "the faithful execution of the laws even where an administration seeks to avoid enforcing congressional acts").

98. Although this criticism could apply to any legal standard that must be applied by numerous courts, the strong public interest inherent in cases involving possible misconduct by high-ranking government officials uniquely calls for a single standard of justice applicable in all situations.

99. Although plaintiff' skills vary widely in cases involving other major issues as well, litigants in areas in which strong public interests are involved (e.g., school desegregation) have often received assistance from powerful organizations such as the NAACP and the ACLU. It is not certain that plaintiffs in cases alleging misconduct by government officials would receive such assistance.

100. See supra note 73 . 
procedure would empower any individual to transform a private allegation against a high-ranking executive branch official into a widely publicized judicial proceeding. Further, the invocation of the judicial process would dignify such charges regardless of how groundless they ultimately proved to be. ${ }^{101}$ The possibility for abuse of sucli a 1neclianism was illustrated in historical terms by one constitutional scholar who observed that allowimg private citizens to play sucli an integral role in this area could usher in a new era of McCarthyism. ${ }^{102}$

Because the court in whicli a private citizen could sue would possess the authority to affirm the Attorney General's determination that the charges were groundless, the specter of McCarthyisin nay well be overstated. However, the numerous problems that would arise from a provision conferring standing upon private parties who subimit information to the Attorney General to challenge his Ethics Act decisions indicate that this is not a good solution to the ineffectiveness of the current statute.

2. Make the Congressional Oversight Mechanism Effective by Giving Congress the Power to Seek Writs of Mandamus to Compel Compliance by the Attorney General. A second inethod for guarding against abuse of discretion by the Attorney General under the Ethics Act would be to alter existing Section $595(\mathrm{e})^{103}$ to allow a inajority of the ineinbers of either party on the House or Senate Judiciary Committees to apply to the Umited States District Court for the District of Columbia for a writ of inandamus commanding the Attorney General to coinply witli the terms of the statute. This power could be utilized, for instance, if a requisite number of the specified ineinbers of Congress felt that the Attorney General had refused to conduct a preliminary investigation even though he had received what was clearly specific information from credible sources, or that he had declined to apply for the appomtment of an independent counsel even though a preliminary investigation showed that there were reasonable grounds to beheve that further investigation or prosecution

101. Provision for Special Prosecutor, supra note 91, at 29-30 (statement of Attorney General Edward Levi) (the fact that any charge would be disseminated and dignified by such a process "would inevitably encourage those who wish to use it for partisan or other improper purposes").

102. See Letter from Prof. Philip B. Kurland to Sens. Ribicoff and Percy (July 8, 1976), reprinted in 122 CoNG. REc. 23,044-45 (1976). Professor Kurland warned that:

The special prosecutorial mechanism could be triggered whenever a charge of misfeasance, malfeasance, or nonfeasance was levelled by any person who chose to make such a charge. This is what I term the "Joe McCarthy" aspect. Just imagine if each of the phony McCarthy charges aganist executive branch officials were to require special prosecutors to investigate and prosecute. Just imagine the official Cohens and Schines who might offer such charges. Just imagine the extraordinary number of unofficial imdividuals eager to assert Id. such charges.

103. See supra note 76. 
was warranted. Such a provision was included in some of the predecessor bills to what eventually became the Ethics Act. ${ }^{104}$

One advantage that this suggestion has over the private attorney general concept is that enforcement of the legal duties of the Attorney General by mandamus obtained by the House or Senate Judiciary Committees would not necessarily imvolve the disclosure of the facts of an allegation or prosecution that would result from hitigation initiated by a private party in open court. ${ }^{105}$ Further, the decision to seek a court order would be made by officials who might be held accountable, at least politically, for abuse of the process.

One problein with such a mechamism, however, stems from the very fact that it would be politicians, often of the opposite party of the individual accused of criminal conduct, who would be making the decision to go to court. Of course, the district court would make the ultimate decision as to the legality of the Attorney General's actions, but this does not totally remove the possibility that an application to the court could be used for political purposes as a means of challenging the integrity of a member of the rival political party. In addition to being pohtical, Congress is not primarily an investigative body. Therefore, another problem with this approach is that only in the most extraordinary and highly publicized cases would Congress learn enougli facts about a particular situation to allow it to make a reasoned decision as to whetlier to seek a court order. ${ }^{106}$ Less publicized but still important cases imight escape the notice of a body as unwieldy as Congress. ${ }^{107}$

Yet another drawback of such a proposal is that it is doubtful that Congress could respond adequately to a rapidly-developing situation even if it had knowledge of the facts. ${ }^{108}$ Thus, although a inechanism providing for effective congressional oversight does not seem to pose as

104. See H.R. 2711, 95th Cong., 1st Sess. (1977); H.R. 8125, 95th Cong., 1st Sess. (1977); H.R. 8538, 95th Cong., 1st Sess. (1977); H.R. 10669, 95th Cong., 2d Sess. (1978); H.R. 10868, 95th Cong., 2d Sess. (1978).

105. See Provision for Special Prosecutor, supra note 91, at 160 (statement of Prof. Archibald Cox).

106. Id. at 114 (statement of Charles Ruff, Watergate Special Prosecutor Force). This problem is exacerbated by the fact that "under present law, it is left entirely up to the Attorney General to determine whether Congress or the public will even know whether there lave been allegations of high-level misconduct, whether these allegations have been investigated, and the results." 126 CONG. REC. 15,264 (1980) (statement of Sen. Weicker).

107. Although it would be the House and Senate Judiciary Committees ratler than the entire Congress that would have the power to seek writs of mandamus against the Attorney General, these committees lave numerous duties to discliarge and would be unable to concentrate a great deal of attention on the propriety of the conduct of large numbers of executive officials.

108. Provision for Special Prosecutor, supra note 91, at 160 (statement of Prof. Archibald Cox) (questioning "whether in the typical crisis . . . Congress could really respond rapidly enough to address very practical problems of conducting an investigation or conducting a prosecution"). 
many serious problems as the private attorney general notion, it is still not the best solution.

3. Allow the Special Three-Judge Panel to Review the Ethics Act Decisions of the Attorney General. A third proposal to amend the Ethics Act and remove the potential for the Attorney General to thwart the process in its early stages is to give added power to the special threejudge panel created by the statute. This proposal would vest in the court the power to review decisions not to conduct a preliminary investigation and not to apply for the appoimtment of an independent counsel. 109

This proposal shares the advantage that characterizes the two previously discussed: helping to safeguard agamst politically motivated decisions by the Attorney General not to invoke the independent counsel mechanism. Further, review of the Attorney General's actions sua sponte by the court would prevent the premature leaking of potentially damaging accusations that would result if private citizens were allowed to bring suit. ${ }^{110}$ Finally, the fact that federal judges are at least somewhat politically insulated makes it less likely that their determination would be influenced by partisan considerations.

Despite these favorable points, there would be problems involved in fitting this sort of sua sponte judicial review imto the existing statutory scheme. For instance, such review would greatly increase the workload of the panel. In assigning judges to the special panel, priority is given by

109. Although it is beyond the scope of this note to consider the possible constitutional objections that may be raised to the various proposals, it should be noted that with regard to the envisioned functions the special three-judge panel would be sitting as a panel of appointment to consider the appointment of an officer of the Umited States as authorized under section 2 of article II of the Umited States Constitution. One constitutional expert has stated that "[t]hese functions, which are clearly related to, and concomitants of, the power of appointment are . . . in my judgment soundly constitutional." Letter from Prof. Paul J. Mishkin to Sen. Ribicoff (May 10, 1976), reprinted in 123 CONG. REC. 20,997-98 (1977).

Under the current version of the Ethics Act, the special three-judge panel has the power, upon receipt of an application from the Attorney General, to appoint an appropriate independent counsel and to define that independent counsel's prosecutorial jurisdiction. 28 U.S.C. $\S 593(\mathrm{~b})$ (1982). The court is also empowered to fill any vacancy that may occur in the office of imdependent counsel, \$ 593(e), and to reveal documents that it receives from the Attorney General to outside individuals. $\$ 592(b)(3)$, (d)(2). The court has no power to review decisions of the Attorney General as to whether to seek appointment of an imdependent counsel. § 592(f).

A provision vesting such power of review in the court would build upon a recommendation made by the American Bar Association in 1976 while Congress was considering what form the legislation should take. Watergate Reorganization and Reform Act of 1975: Hearings on S. 495 and S. 2036 Before the Senate Comm. on Government Operations, 94th Cong., 1st Sess. 164 (1975) (testimony of William B. Spann, Jr., President-Elect Nommec of the ABA) (explaining ABA's proposal that "[t]he special court of appoimtment could act on its own in appointing a temporary special prosecutor where [the situation deinonstrates] the necessity for such an appomiment and the Attorney General has refused").

110. See supra notes $100-02$ and accompanying text. 
statute to senior circuit judges and retired justices. ${ }^{111}$ Under the current version of the Ethics Act, the primary responsibility given to the threejudge panel is to appoint an independent counsel upon receipt of an application froin the Attorney General and to define that independent counsel's prosecutorial jurisdiction. ${ }^{12}$ Given the infrequency with which allegations under the Ethics Act reacli this stage, the special panel niay convene only a few times per year. It is likely that the non-strenuous nature of tliese duties is the primary reason that Congress decided to staff the special panel with retired judges.

If the three judges are given the sole responsibility for guarding against abuse of discretion by the Attorney General under the Ethics Act, their burden will be significantly increased both in terms of the frequency with which they will have to sit and the difficult nature of the decisions that they will have to inake based upon a linited record. It is quite possible that retired judges miglit not be able to perform adequately under this strain. ${ }^{113}$ One scliolar, commenting on a similar proposal, stated that to "entrust thein witl charge of lighly volatile political affairs is to put dynamite in the hands of the incoinpetent."114 While this inay be a soinewliat harsh assessnient of the capabilities of the judges who are likely to coinprise the special panel, it is obvious that sonie revamping of this body is necessary before it could be expected to handle the great oversiglit responsibility conferred upon it by this proposed aniendinent. The simplest way to accoinplisl this would be to staff the three-judge panel witl sitting rather than senior judges.

Anotler problem with this proposal under the existing statutory sclenne involves the sort of record that will be available for the special panel to review in determining whether the Attorney General reached a correct decision. Section 592(a)(1) ${ }^{115}$ would liave to be changed to compel the Attorney General to provide the court with all of the information that he lias received, ratlier thian simply allowing him not to conduct a preliminary investigation, upon determining that the information is not sufficiently "specific" or did not coine froin "credible" sources. Such a

111. 28 U.S.C. $\$ 49(c)(1982)$.

112. 28 U.S.C. at $\S 593(b)(1982)$.

113. See Letter from Prof. Philip Kurland to Sens. Ribicoff and Percy (July 8, 1976), reprinted in

122 CoNG. REC. 23,044-45 (1976). Professor Kurland cautioned that:

You must not think of serior federal judges in terms of Learned Hands or Henry Friendlys. Let me assure you that those are the exceptions rather than the rule. Most superannuated judges were of no great competence while they performed active service and have simce necessarily retired for age and the mental deterioration that age brings on.

Id. The three semior circuit judges currently comprising the special panel are Judges Robb, Mansfield, and Morgan, ages 77, 73, and 71, respectively.

114. Id.

115. See supra note 5. 
provision would give the special panel the requisite data to determine whether a preliminary investigation is in fact warranted. That the preliminary investigation would be conducted by the Justice Department may give rise to questions regarding the thoroughness of the probe that the special panel would review if the Attorney General decides not to apply for the appointinent of an independent counsel. However, such a danger already exists under the current statute, and the ouly way to eliminate it would be to estabhish a separate entity to conduct the investigation.

Of critical importance in such a scheme would be the legal standard that the special panel would utilize in reviewing the Attorney General's Ethics Act decisions. Although the decision reviewed by the panel would be akin to an agency action, a familiar administrative law standard such as "supported by substantial evidence on the record" may prove unmanageable due to the difficulty of defining the "record" in such a case. ${ }^{116}$ However, allowing the court to inake its own independent determination as to what decisions should have been reached would seem to render the Attorney General's function of screening clearly frivolous allegations superfluous. Therefore, in order to retain a vital role for a properly motivated Attorney General, the legal standard to be applied should be whether the decision was "clearly erroneous," or contrary to the information possessed by the court. Such a standard would guard against abuse of discretion by the Attorney General while at the saine time preserving his screening function to soine extent.

Overall, it appears that most of the probleins that would arise froin an amendinent allowing the special panel to review sua sponte the decisions made by the Attorney General result from defects in other provisions of the Ethics Act as it currently stands. Simple adjustments in these sections to create a more vital special panel and to coinpel the Attorney General to provide it with the information he receives concerning each allegation would inake this proposal a possible solution to the problems with the current Ethics Act while at the same time retaining the basic frainework of the present statute.

4. Establish an Independent Law Enforcement Agency to Administer the Ethics Act. Solne of the predecessor bills to what eventually becaine the Ethics Act provided for a specialized entity to deal solely with

116. For example, one problem would be whether the special panel could consider information other than that provided to it by the Justice Department as part of the "record." A possible solution to such problems would be to give the court some discretion to define the scope of the record. 
crimes committed by government officials. ${ }^{117}$ Such proposals were flawed, however, in that the agencies that they proposed were to be within the Justice Department. This factor raises the specter of lack of independence, which could hardly be said to solve the problein of undue influence by the Attorney General over the triggering of the independent counsel inechanisin.

A more effective solution, one not previously suggested, would be to establish an independent law enforcement agency, analogous to, but much sinaller than, the Federal Trade Commission (FTC). The proposed agency, charged by Congress with administering the Ethics Act, could consist of three commissioners appointed by the president and confirmed by the Senate for staggered terms, with not more than two commissioners being members of any one political party. ${ }^{118}$ This "Independent Counsel Commission" could be empowered to receive information from any source concerning alleged criminal conduct by officials covered by the Ethics Act and to evaluate it inuch as the Attorney General is bound to do under tlie current statute. If warranted, the Commission could order a preliminary investigation of the matter, and, upon considering the results of such a probe, apply to the special threejudge panel for the appoimtment of an independent counsel. The duties of the Independent Counsel Commission could end at this point, leaving open to the criminal defendant the safeguards, includimg tlie right to a grand jury and a trial by jury, available in federal court should charges ultimately be brought by the independent counsel.

The idea of creating an independent commission to admimister the Ethics Act has several significant advantages over the three proposals for reform previously discussed. The Independent Counsel Commission could conduct its proceedings in caniera, thereby avoiding the problem of preinature disclosure of unsubstantiated allegations that would result from conferring standing upon private citizens to challenge the decisions of the Attorney General. 119 Only one body would be making decisions as to whether or not to conduct preliminary investigations or seek appointinent of an independent counsel, eliminating the danger of a multiphicity of standards that would arise if every district court were allowed to make such decisions. ${ }^{120}$ Further, use of the commission process would ensure that the result would not depend upon the capability of a single individ-

117. See, e.g., S. 495, 94th Cong., 2d Sess. (1976) (providing for a Division of Government Crimes within the Justice Department).

118. Cf. 15 U.S.C. $\S 41$ (1982) (providing details as to the structure of the FTC).

119. See supra text accompanying notes 100-02.

120. See supra text accompanying notes 30-35. 
ual to litigate effectively. ${ }^{121}$

The fact that not more than two of the three commissioners could be members of the same political party would help to ensure that their decisions would not be influenced unduly by political considerations, a safeguard not present in the proposal for increased congressional oversight. ${ }^{122}$ Further, unlike Congress, the Independent Counsel Commission would have the flexibility to learn the facts behind allegations made to it and to respond rapidly enough to developing situations to administer the Ethics Act effectively. ${ }^{123}$

Because the Independent Counsel Commission would be the body to which information concerning allegations of misconduct by executive officials would originally be presented, some of the problems that plague the idea of sua sponte review of the Attorney General's decisions by the special three-judge panel would be eliminated. For example, there would be no problem in determining what could be considered part of the "record" or what legal standard should be apphied.124 Further, the creation of a commission would eliminate the need to replace the senior judges on the special panel with active judges. ${ }^{125}$

On the whole, the proposal for an Independent Counsel Commission to assume the duties assigned to the Attorney General under the current scheme is more sensible than the three proposals previously discussed. The three other possible amendments would relegate the Attorney General to the role of merely ordering a preliminary investigation or applying for an independent counsel; any contrary decision by him would be subject to review. It would be more efficient simiply to bypass the Attorney General altogether rather than to assign to him this pedestrian task.

An mipartial commission of this sort would provide a solution to the existimg probleins with the Ethics Act, but tlie proposal has some practical drawbacks. Unlike the FTC, the Independent Counsel Commission may not receive enough complaints to keep it busy. Besides inaking tlee commission a waste of the taxpayers' money, sucll a situation could make it difficult to find qualified imdividuals willing to serve as commis-

121. Id.

122. See supra text accompanying notes $36-51$.

123. See supra text accompanying notes 106-08.

124. See supra text accompanying note 116.

125. The danger of laving three active judges with little to do is a more likely prospect than the danger that the Independent Counsel Commission would not have a sufficient workload. The special panel would come into play only in situations where it appears that the Attorney General has abused his discretion, whereas the commission would have the additional duty of making decisions as to whether to conduct a preliminary investigation or seek appointment of an independent counsel in the first instance in all cases. 
sioners. Further, a lack of work could lead the commission to accord undue weight to the allegations that it does receive and might create a tendency to apply for an independent counsel in unimportant cases in an attempt to justify its existence. However, the existence of such a commission might encourage submission of substantial allegations from soine mdividuals who would otherwise remain silent due to their belief that a partisan Justice Department would give their charges short shrift. 126 Given the number of allegations of criminal conduct by high government officials that are made annually, the proposed commission may well find itself with an adequate workload. ${ }^{127}$

Another potential problem with this proposal is the question of who would conduct any preliminary investigation ordered by the commission. If the probe were done by the Justice Department, there would be the danger of a cover-up engineered for political purposes. However, this saine problem exists as the Ethics Act is currently structured, and the fact that the Independent Counsel Commission would review both the mitial allegations and the results of any investigation increases the possibility that at least the more blatant attempts to cover up serious allegations would be revealed. No such safeguard exists under the present statute.

Even though the idea of an imdependent agency to enforce the Ethics Act avoids some of the problems with the three proposals previously discussed, it may prove difficult to achieve the congressional support necessary to create such a body. Bills providing for a permanent office of special prosecutor have been rejected by previous Congresses, ${ }^{128}$ and the current trend toward reducing the size of the governmental bureaucracy would work against the proposal to establish another agency. But the Independent Counsel Commission would consist of only three members and would utilize the Department of Justice to conduct its preliminary investigations, and therefore the number of support personnel required would be small.

\section{Further, the}

mere existence of an authority outside the Department of Justice and the Executive Braneh which can make the appointunent of a teinporary special prosecutor will act as a substantial deterrent to extreme situations such as Watergate. There are those who beheve that campaign misconduct and misconduct by high-level government officials are not rare but simply flourish when there is hittle reason to fear prosecution.

S. REP. No. 170, 95th Cong., 1st Sess. 7 (1977).

127. In testimony before a House subcommittee concerning special prosecutor legislation, a high-ranking Justice Department official stated that the Attorney General receives "hundreds of letters froin citizens coinplaining about and making allegations of misconduct." Special Prosecutor Legislation, supra note 90, at 6 (statement of Acting Assistant Attorney General John M. Harmon).

128. See, e.g., H.R. 14795, 94th Cong., 2d Sess. (1976) (proposing creation of an office of Special Prosecutor with threc-year term and removal only for extraordinary impropriety). 
Further, the Justice Department may actually favor a proposal that reheved it of the duty to make difficult decisions whether to investigate or prosecute fellow administration members. Under the current version of the Ethics Act, the Justice Department must either decline to trigger the independent counsel process, in which case it is often accused of engaging in a cover-up for political purposes, or clioose to proceed even tliough the allegations are seemingly frivolous, in which case the public official involved is subjected to a harsher standard of justice than would be applied to a private citizen. ${ }^{129}$ An independent agency would be free to inake the decision not to proceed without being accused of having partisan motivations. ${ }^{130}$

\section{CoNCLUSION}

More tlian a century ago, the Supreme Court expounded a clear definition of the proper ethical standard for government officials:

No inan in this country is so high that he is above the law. No officer of the law may set that law at defiance with impuirity. All of the officers of the government, from the highest to the lowest, are creatures of the law, and are bound to obey it. It is the only supreme power in our systein of government, and every man who by accepting office participates in its functions is only the more strongly bound to that supreinacy, and to observe the limitations which it imposes upon the exercise of the authority which it gives. ${ }^{131}$

In 1978 , in a belated reaction to the Watergate affair, Congress atteinpted to effectuate suclı a standard of conduct by passing the Ethics in Government Act, which was designed to prevent the executive branch from tliwarting, out of political expediency, attempts to prosecute higlı executive officials for serious criminal conduct. As the Nathan and Banzhaf cases have demonstrated, lowever, the Ethics Act as presently drafted allows the Attorney General to make nonreviewable, discretionary decisions that can short-circuit tlie independent counsel inechanism. In order to fully accomphish the stated purpose of the Ethics Act, Congress must amend it to provide for some sort of review of the Attorney

129. See S. REP. No. 496, 97th Cong., 2d Sess. 12 (1982) (Ethics Act "creates unfairness by imposing a stricter application of criminal law on public officials than that imposed on private citizens" and "wastes valuable Department of Justice resources by requiring high priority investigations in situations where no one else would be investigated").

130. The Attorney General is a political appointee whose job, in some ineasure, is dependent upon political considerations. Even an Attorney General who seeks to apply the Ethics Act with coinplete objectivity may be subjected to political pressure from other members of the executive branch. By taking the decision out of his hands, the Independent Counsel Commission may be removing from the Attorney General one of his most unpleasant tasks-deciding whether or not to investigate a person with whoin lie is politically affiliated.

131. United States v. Lee, 106 U.S. 196, 220 (1882). 
General's decisions or remove those decisions from him entirely. The idea of creating an independent law enforceinent agency to administer the Ethics Act seens to be the best of the proposals discussed in this note, but any one of them would improve upon the existing statute. All therefore inerit serious congressional consideration.

Stephen Charles Mixter 